\title{
Nanopharmacology in translational hematology and oncology
}

\author{
This article was published in the following Dove Press journal: \\ International Journal of Nanomedicine \\ 22 July 2014 \\ Number of times this article has been viewed
}

\author{
Ciprian Tomuleasa ${ }^{1,2, *}$ \\ Cornelia Braicul,* \\ Alexandra Irimie ${ }^{3}$ \\ Lucian Craciun' \\ loana Berindan-Neagoe ${ }^{1,4,5}$ \\ 'Research Center for Functional \\ Genomics, Biomedicine and \\ Translational Medicine, luliu Hatieganu \\ University of Medicine and Pharmacy, \\ ${ }^{2}$ Department of Hematology, \\ Ion Chiricuta Cancer Center, \\ ${ }^{3}$ Department of Prosthetic Dentistry \\ and Dental Materials, ${ }^{4}$ Department \\ of Immunology, luliu Hatieganu \\ University of Medicine and Pharmacy, \\ ${ }^{5}$ Department of Functional Genomics \\ and Experimental Pathology, the \\ Oncological Institute "Prof Dr Ion \\ Chiricuta", Cluj-Napoca, Romania \\ *These authors contributed equally \\ to this work
}

\begin{abstract}
Nanoparticles have displayed considerable promise for safely delivering therapeutic agents with miscellaneous therapeutic properties. Current progress in nanotechnology has put forward, in the last few years, several therapeutic strategies that could be integrated into clinical use by using constructs for molecular diagnosis, disease detection, cytostatic drug delivery, and nanoscale immunotherapy. In the hope of bringing the concept of nanopharmacology toward a viable and feasible clinical reality in a cancer center, the present report attempts to present the grounds for the use of cell-free nanoscale structures for molecular therapy in experimental hematology and oncology.
\end{abstract}

Keywords: hematological malignancies, nanoparticles, translational medicine

\section{Introduction}

Nanopharmacology is an interdisciplinary research field, which was developed as an interaction between chemistry, engineering, biology, and medicine, and it is currently receiving growing interest in the clinic. ${ }^{1}$ Progress in nanotechnology has gained attention in recent years by developing novel nanoparticle-based drugs or by discovering novel applications in early diagnostic or prognostic assays in cancer. ${ }^{2}$ Multiple preclinical studies aim to improve the therapeutic index of a patient diagnosed with cancer using a wide range of nanostructures including carbon nanotubes, peptides, nanodiamonds, cyclodextrine, graphenes, liposomes, quantum dots, nanowires, and metal-based nanoparticles.,

The latest advances in nanotechnology have brought various options that could be used in the clinic by employing constructs for molecular diagnosis, disease detection, cytostatic drug delivery, and nanoscale immunotherapy. ${ }^{5-8}$ The United States Food and Drug Administration has approved the use of liposome-encapsulated doxorubicin (Doxil ${ }^{\circledR}$; Janssen Products, LP, Johnson \& Johnson, New Brunswick, NJ, USA) and paclitaxel attached to nanoparticles (Abraxane ${ }^{\circledR}$; Celgene Corporation, Summit, NJ, USA $)^{9,10}$ in cancer therapy.

In this review, we present the latest investigation on nanostructure systems with applications in hematology and oncology. The latest advancements in nanopharmacology lead to heightened expectations concerning their application in diagnostics, therapy and imaging.

\section{Drug nanocarriers in cancer pharmacology}

In the last few years, our team has shed a new light on the field ${ }^{11,12}$ by different conjugation procedures for these therapeutics. Overcoming this threshold bears major clinical significance in oncology and hematology, as developing nonviral gene delivery vehicles will bring new patient-tailored drugs within reach (Figure 1). The transport of therapeutic nucleic acids through the cell membrane is inefficient mainly
Research Center for Functional

Genomics and Translational Medicine,

"Iuliu Hatieganu" University of Medicine and Pharmacy, Cluj-Napoca, 23 Marinescu Street, 400I 5, Romania

Tel +40 264450749

$\mathrm{Fax}+40264598885$

Email ioana.neagoe@umfcluj.ro 


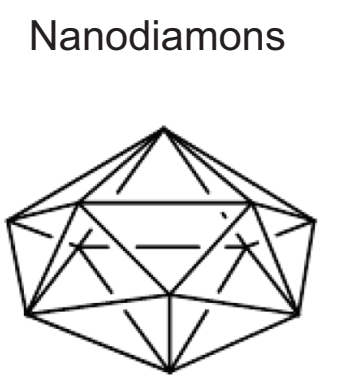

Carbon nanotubes

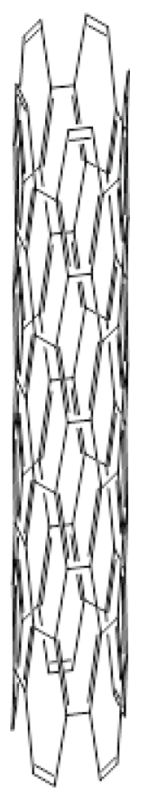

Figure I Nanoparticles used in medicine.

in experimental models and includes antisense or antigene oligonucleotides, short interference ribonucleic acid (siRNA) or micro ribonucleic acids (miRNA). ${ }^{13,14}$

Surgical resection in early tumor stages is the main therapeutic option for most solid malignancies, yet therapeutic benefits are frequently modest because of the high rate of tumor recurrence. ${ }^{15}$ Chemotherapy and, more recently, molecular therapy, were proven to offer much more efficient therapeutic approaches for patients diagnosed with cancer. ${ }^{2}$ Nevertheless, these options are most often accompanied by important systemic side effects associated with the active agent, making a direct delivery the most "elegant" and efficient therapeutic option. The direct delivery of chemotherapy drugs aims to achieve high concentrations of the cytostatic agents at the target site with minimized risk of systemic toxicity (Figure 2). ${ }^{16}$

\section{Viral vectors}

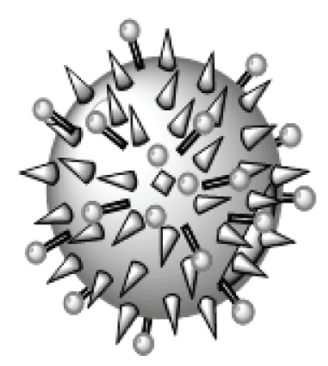

Peptides

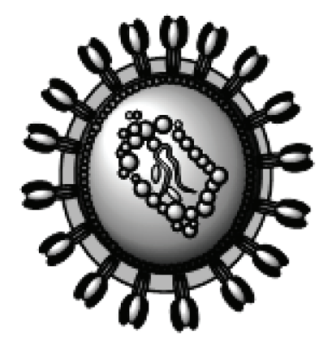

Dendrimers

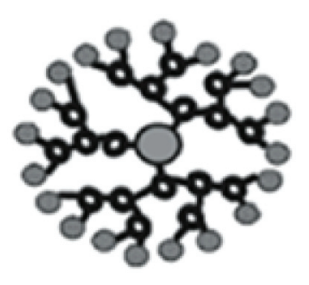

In cancer chemotherapy, the clinician aims to achieve a good therapeutic index, which is the ratio of the lethal dose for $50 \%$ of the population to the minimum effective dose for $50 \%$ of the population. ${ }^{17}$ However, cancer is most often characterized by multidrug resistance (MDR) and thus scientists have developed new ways to target the MDR cells. ${ }^{18}$ MDR cells are known to be frequently located in hypoxic areas, distant from any blood supply, thus overcoming the natural barrier of drug efflux pump activity. ${ }^{18}$ Such smart molecules may increase the drug's bioavailability and transform an active agent from a low therapeutic candidate into a highly efficient drug. A wide variety of both organic and inorganic substances are used for engineering nanostructures, such as liposomes, micelles, nanoemulsions, polymers, quantum dots, gold, iron oxide, and even dendrimers. ${ }^{19-22}$ All these structures were developed in order to have a large surface area, making these 


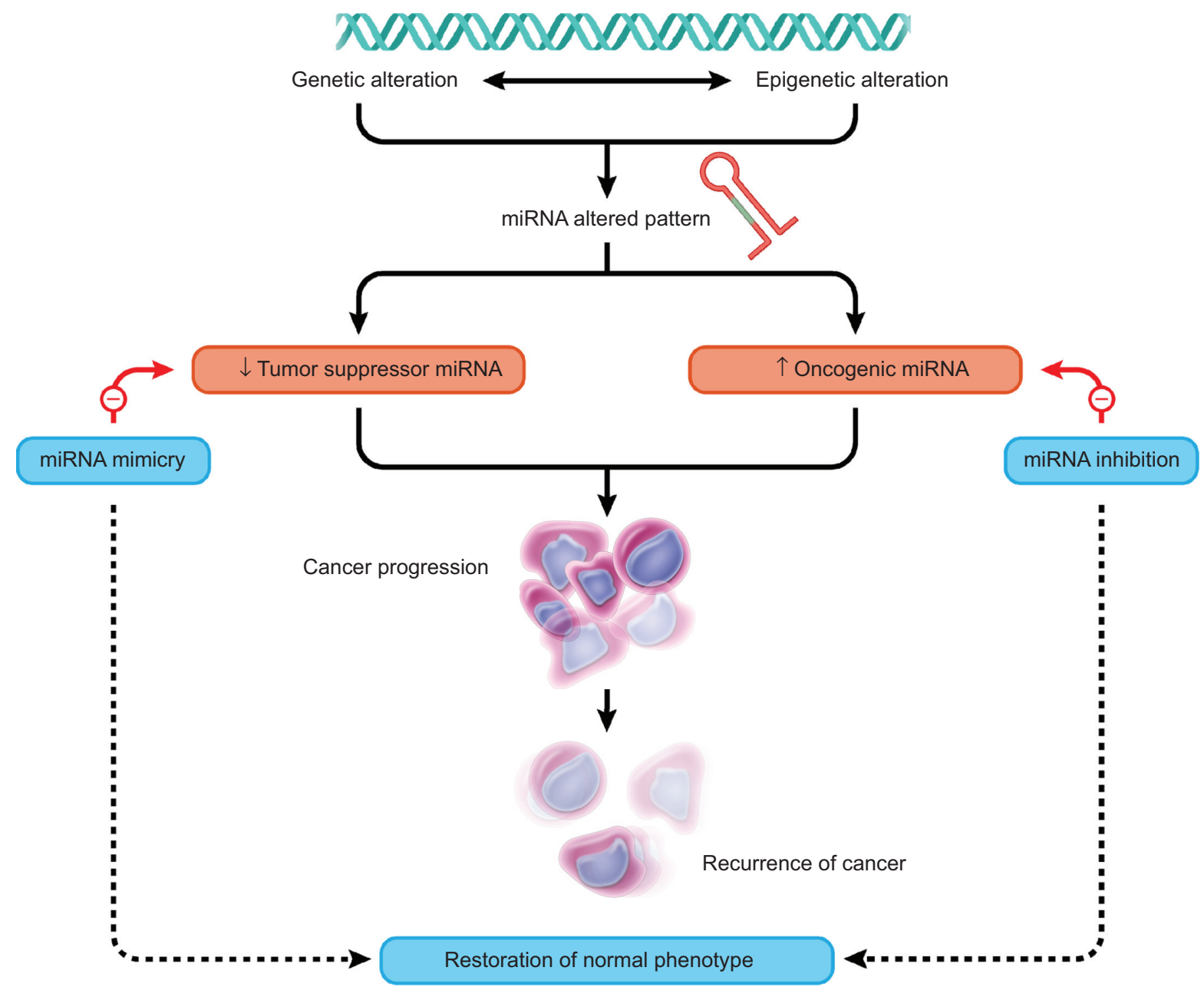

Figure 2 miRNA-based approaches in cancer therapy.

Abbreviation: miRNA, micro ribonucleic acid.

particles suitable for suspension storage, as well as high drug encapsulation and extensive surface absorption capacity, which are pharmacokinetic features that are found in any current structure used in classical pharmacology. ${ }^{23}$ However, the most important aspect, especially for cancer, is that nanocarriers are able to bypass the extracellular efflux activity of the adenosine triphosphate-binding cassette transporters in order to be internalized via nonspecific endocytosis, ${ }^{24-26}$ such as the case of immunoliposomes ${ }^{27,28}$ and poly (butyl)-cyanoacrylate nanoparticles. ${ }^{29,30}$ At the same time, the nanocarriers use surface charge-switchable polymeric magnetic nanoparticles as a safe delivery system. ${ }^{31-33}$ In this way, the active agent is released near the nucleus, far away from the membranebound P-glycoproteins, which is of paramount importance when trying to overcome the resistance to conventional chemotherapy of cancer stem-like cells. ${ }^{34-36}$

Ozeki et $\mathrm{al}^{37,38}$ have experimented with a new drug delivery model in malignant gliomas. They managed to bypass the blood-brain barrier by using a unique thermo-reversible hydrogel, composed of drug/poly(lactic-co-glycolic acid) (PLGA) microspheres. This thermo-reversible polymer is a gel at body temperature and a sol at room temperature conditions in which the drug/PLGA microspheres dispersed in the polymer are injected into the human body. Following the procedure, a gel forms around the injection site; this keeps a high concentration of the active substance in the tumor, preventing its dispersion in adjacent healthy tissues..$^{39}$ Devalapally et $\mathrm{a}^{40}$ used poly(epsilon caprolactone) nanostructures whose surface has been modified with poly(ethylene glycol) (PEG) before being loaded with tamoxifen and paclitaxel for the treatment of multidrug-resistant cancer cells. The results were encouraging, as this combination resulted in a lower therapeutic dose of the cytostatic agent, with important clinical applications regarding chemotherapy-related side effects.

The first groundbreaking drug was doxorubicin encapsulated in circulating liposomes (Doxil) for the treatment 
of Kaposi's sarcoma in patients diagnosed with acquired immunodeficiency syndrome (AIDS). ${ }^{41}$ Recently, this therapeutic option has been applied for other cancers such as breast cancer, since doxorubicin encapsulated in liposomes induces a twofold increase in intracellular drug levels when compared to standard doxorubicin treatment. ${ }^{42}$ Doxil is a PEGylated liposomal drug that has a $100 \mathrm{~nm}$ diameter in order to prevent the interaction with plasma proteins such as opsonins and high-density lipoproteins (HDLs) and low-density lipoproteins (LDLs), or to avoid elimination by macrophages. ${ }^{43-45}$ After the conjugation of a liposome with PEG (a process called PEGylation), the new drug can stay in the systemic blood flow for longer periods of time due to the development of an aqueous layer on the surface of the liposome, leading to a lack of immune recognition and rejection. ${ }^{46,47}$ This results in the stabilization of the lipid bilayer and steric hindrance, with important consequences such as decreasing protein absorbance and recognition by the host's macrophages. ${ }^{48}$ Many reports show the ability of various gold/silver nanoparticles or carbon nanostructures to enhance the antitumor effect of certain drugs. ${ }^{23}$ However, in hematology, HDL nanostructures target the scavenger receptors (B1) and promote cholesterol efflux in lymphoma cells. ${ }^{49}$ Indirectly, these exogenous lipoproteins inhibit lymphoma growth and invasion by starving the malignant cell, ${ }^{50,51}$ thereby aiding the classic chemotherapy regimen.

PEGylated liposomes loaded with docetaxel, and prepared using the thin film hydration method, showed enhanced in vitro cytotoxicity against A549 and B16F10 cells when compared to Taxotere $^{\circledR}$ (Sanofi-Aventis, Bridgewater, NJ, USA). ${ }^{52}$ The capacity of a self-nanoemulsifying drug delivery system was assessed in order to increase the bioavailability of docetaxel and, consequently, its therapeutic activity. ${ }^{53}$ This study showed that a self-nanoemulsifying drug delivery system exhibited superior efficacy with low associated toxicity when compared to the commercialized formulation of this bioactive agent (Taxotere). ${ }^{53}$

In recent years, gold nanoparticles have also emerged as therapeutic options for the targeted delivery of antineoplastic active substances, due to their special chemical and physical properties such as functional versatility, biocompatibility, and low toxicity. ${ }^{54-56}$ Apart from being of small size (30-50 nm in diameter), ${ }^{57}$ naked gold nanostructures have a plasmon absorption in the near-infrared region and display strong photothermal ability. These structures lack a silica core, have a spherical shape, and have a strong and tunable absorption band between $550 \mathrm{~nm}$ and $\sim 820 \mathrm{~nm} .{ }^{58-61}$ These properties make them highly efficient carriers of various drugs already used in the clinic. Their effect has already been shown by our team in malignant gliomas and hepatocellular carcinoma for temozolomide, cisplatin, doxorubicin, and capecitabine. ${ }^{62}$

Diamonds can provide a very efficient delivery system for some chemotherapy agents. In the last few months, nanodiamonds have emerged as potential carriers in neuro-oncology or hemato-oncology. Xi et $\mathrm{al}^{63}$ have conjugated nanodiamonds with doxorubicin and used convection-enhanced delivery for supratentorial tumors in a murine model. Man et al ${ }^{64}$ have also used nanodiamonds to deliver another type of anthracycline to multidrug-resistant malignant cells. They showed that acute myelogenous leukemia, often leading to patient death in the clinic because of resistance to chemotherapy, might be managed by a nanotechnology-based targeted delivery of daunorubicin to the hematological malignancies. Camptothecin is a natural hydrophobic anticancer drug that could be potentially used for breast adenocarcinoma management if delivered correctly at the tumor site. ${ }^{65}$ Delivery can be achieved using nanotechnology, as is the case of the self-assembling peptide amphiphile nanofibers. Soukasene et $\mathrm{al}^{66}$ proved this concept in a mouse orthotopic model of breast carcinoma. Camptothecin was also confirmed by Min et $\mathrm{al}^{67}$ to be efficient in breast chemotherapy when delivered to malignant cells, by encapsulating it in modified glycol chitosan nanoparticles, thereby achieving a high concentration with minimal side effects in healthy tissues, after having used subcutaneously implanted xenografts in immunocompromised mice. Since monoclonal antibodies are increasingly used in clinical oncology, some investigators have tried to add the targeted effect of antibody-based drugs to a nanocarrier in order to obtain maximum anticancer effects with minimal side effects. ${ }^{2,23}$ Thus, trastuzumab was conjugated with various nanostructures, including carbon nanotubes or nanospheres. ${ }^{68}$ The desired effect was achieved and, in the near future, we may expect newly described cytostatic agents in Phase I or Phase II clinical trials.

Immunotherapy is a very important part of the multimodal approach in cancer management. The immune system may also influence the outcome of a certain regimen. $\mathrm{Ni}$ et $\mathrm{al}^{69}$ have applied this concept by developing a local vaccine after conjugating graphene oxide targeting interleukine-10 receptor. Thus, the anti-inflammatory action of interleukin-10 is blocked and the suppressive tumor microenvironment becomes a target for the immune system.

Nanovectors can be used as carriers for drugs, but also for contrast substances, with a high applicability in diagnostic medicine..$^{70}$ Iron oxide, gold, gadolinium, or even quantum 
dots represent good alternatives for radiation oncology, photodynamic therapy, or hyperthermia. ${ }^{71,72}$ Iron oxide has important superparamagnetic characteristics and is one of the most investigated nanostructures in diagnostics, including in lymph node imaging, the inhibition of cancer cell dissemination and stem cell trafficking, visualization of ribonucleic acid (RNA), interference and T-cell-specific labeling. ${ }^{73-77}$ As a contrast agent, iron oxide is especially useful for magnetic resonance imaging (MRI), and it is very sensitive in detecting solid tumors, but it has little or no applicability in lymph node micrometastasis or hematological malignancies. ${ }^{78,79}$ While still in the early stages, the research in this field will more than likely improve in the near future. In prostate cancer, Harisinghani et $\mathrm{al}^{78}$ have already proven that the use of iron nanostructures as a contrast agent in MRIs detects over $90 \%$ of all lymph node disseminations, which is in comparison with the detection rate of $35 \%$ in classic MRIs.

Even though chemotherapy remains the most widely used and effective treatment option for disseminated malignancies, acquired or intrinsic drug resistance accounts for almost $90 \%$ of treatment failure. MDR represents the simultaneous resistance to various medications that are different both structurally and functionally, most often as a result of the drug efflux pumps that reduce the intracellular levels and thus reduce the cytotoxic effect on the cancer cell. ${ }^{6}$ New nanotechnologybased theranostics are evolving and are expected to confer new strategies in overcoming the drug efflux transporters, which are findings that are presented further in the next section. The multifunctional characteristics of the nanocarriers make them very suitable for treating a heterogeneous tumor mass in comparison to classic approaches. ${ }^{15}$ Nanocarriers have a preferential accumulation within the malignant cell due to the enhanced permeability and retention effect. ${ }^{23,80}$ Thus, the drug concentration is increased in the malignancy and reduced in the surrounding, healthy tissue. This will result in an increased efficacy of systemic therapy, with decreased side effects. ${ }^{23,70}$

Nanotechnology can be applied not only in chemotherapy, but also in radiation oncology, by combining radiobiology with experimental pharmacology. Malignant cells are sensitive to ionizing radiation emitted by various radioactive metals. ${ }^{81}$ By delivering such substances to the primary tumor site, we may improve current radiotherapy or brachytherapy protocols. Chanda et $\mathrm{al}^{82}$ have conjugated gum arabic glycoproteins to gold nanoparticles and tested this new assay on a murine model of prostate cancer. The administration of a single dose of beta-emitting irradiation increased the local administered dose up to 70 Gy and induced the regression of prostate adenocarcinoma in nude mice. Garrison et $\mathrm{al}^{83}$ also used an in vivo murine model of prostate cancer and demonstrated that beta radiation emitting bombesin could be used to specifically target cancer cells.

\section{Nanocarriers conjugated with miRNAs or anti-miRNA oligonucleotides}

The human body has natural barriers for preventing a wide range of diseases, whether considering the organism/body level, the tissue-organ level, the cellular level, or even the molecular level. Thus, the simple aim of achieving highly localized drug delivery with maximal anticancer effects and minimal side effects is very troublesome, as it can be expensive, time consuming, and it does not offer any guaranteed success. ${ }^{2,23}$ This emphasizes the need to design highly specific carriers that can deliver highly specific active agents in order to achieve maximum efficacy with minimal toxicity. In vivo, various miRs can be delivered either by viral or nonviral carriers, depending on transfection efficiency, the safety of the receiving host, immunogenicity, or side effects. ${ }^{84,85}$ Nonviral carriers are nonetheless considered to be more suitable in the clinic, especially cationic transporters such as PEG. This is because it has a strong buffering ability and it can release functional genetic material into the cytosol after having induced osmotic endosome breakage. ${ }^{86-88}$ The main disadvantage is that PEG is not cell-specific, and one would need very high doses in order to achieve the desired concentration, leading to potentially serious side effects. ${ }^{89,90}$ Thus, the need to improve current knowledge in the field and to produce other ligand molecules for aptamers functionalization. Aptamers are short, single-stranded oligonucleotides formed by $30-50$ bases and they express minimal or even no antigenicity and immunogenicity, making them more suitable for in vivo use in clinical hematology and oncology. ${ }^{91-93}$

Other nonviral vector systems may also include carbon nanomaterials, such as nanotubes or fullerenes. Our studies used nanotubes because of their unique intrinsic physical and chemical properties in an attempt to deliver siRNA in hepatocellular carcinoma cells. ${ }^{12}$ The molecular analysis of the experiments has proven that $\mathrm{p} 53$, TNF- $\alpha$, and VEGF levels were altered after siRNA transfection. This proves that carboxylated carbon nanotubes may provide an alternative to the lipid transfection system-based therapy for liver malignancies. The successful functioning of the endosomal siRNA system and followed by the release of the RNA molecules into the cytoplasm are very important for the efficient use of oncogene silencing. ${ }^{1,2,13}$ In order for this process to be 
carried out with minimal side effects, tertiary complexes were developed out of nucleic acids, polycations, and a chargereversal polymer that can $\mathrm{pH}$-dependently alter its electric charge either into the positive or negative state. ${ }^{94-96}$ When the vector arrives into an organelle such as an endosome or a lysosome, both are known to have a pH of 5-6, the charge conversion facilitates endosomal escape through a membrane disruption process after having enhanced the so-called "proton sponge". ${ }^{97-99}$ Apoptosomes represent other models of molecular self-assembly structures. In such wheel-like structures, an individual Apaf-1 protein will form a complex with cytochrome-c ${ }^{100}$ before recruiting and activating procaspase-9. ${ }^{101}$ This will trigger a cascade of other events, which may lead to apoptosis. Polymeric micelles are artificial structures that resemble apoptosomes and act as either drug solubilizers or carriers of antisense oligonucleotides and drug molecules. ${ }^{102}$ A single-stranded oligonucleotide can recognize a target molecule on a cancer cell both through Watson-Crick base pairing with folic acid, and also through hydrophobic interactions and hydrogen bonding. ${ }^{103}$ Such an oligonucleotide ligand is also known as an aptamer, which has very important properties that include its small size, a lack of immunogenicity, and ease of synthesis. ${ }^{104,105}$

Exosomes are vesicles ranging from $30-90 \mathrm{~nm}$ in diameter, and they are known to play a key role in intercellular communication. ${ }^{106,107}$ This communication is accomplished using various cytokines, interleukins, and a substantial amount of RNA. ${ }^{108}$ RNA carried by the exosomes is mostly a RNA and miRNA messenger, with very little $18 \mathrm{~S}$ and $28 \mathrm{~S}$ ribosomal RNA. ${ }^{109,110}$ Since exosomes are used in normal cell physiology in RNA transport, researchers have attempted to use these nanostructures in gene therapy as a vector to deliver therapeutic nucleic acids to target cancer cells. ${ }^{108,111}$ Gene therapy aims to provide a therapeutic solution for the cause of the disease, rather than for its symptoms. Two types of vectors (either viral or nonviral) are currently available in the US, according to an online search of the National Institutes of Health database (http://clinicaltrials.gov/ct2/home). Most of the 262 ongoing trials use viral vectors, yet this approach is associated with a high toxicity and an important immunological response from the host organ. Exosomes are far more efficient because they can target cancer cells and trigger little or no immune response since they are isolated from the patient's bodily fluids and are subsequently transferred back to the same patient after an insertion or deletion of the genetic material in vitro. ${ }^{12-114}$ Wahlgren et al ${ }^{115}$ used exosome-delivered siRNA in order to achieve posttranscriptional gene silencing. They showed that the MAPK-1 protein was downregulated in both monocytes and lymphocytes that were cocultured with particles, which were genetically modified to carry an anti-MAPK-1 transcript.

Exosomes represent an important delivery system, ${ }^{116,117}$ which proved its efficacy in vitro for RNA and protein transport. ${ }^{118}$ A good therapeutic effect with low immunogenicity was observed for siRNA., ${ }^{1,2,13}$ In a study conducted by Alvarez-Erviti et $\mathrm{al}^{119}$ the capacity to downregulate the BACE1 protein and messenger RNA levels was demonstrated using exosome-mediated siRNA delivery produced by dendritic cells. The same group ${ }^{119}$ has also engineered dendritic cells to express the exosome-specific protein, Lamp2b, fused with the peptide, rabies virus glycoprotein, which is specific for neuronal lineage cells. Thus, dendritic cells synthesized exosomes, which were loaded to exogenous siRNA. This resulted in the knockdown of BACE2. The clinical implications are of great potential in the management of Alzheimer's disease. ${ }^{120}$ Gold is a noble metal used throughout the ages of human history in all aspects of civilization, including in medical science, ${ }^{121,122}$ and nanotechnology-based new approaches make no exception. Polyvalent oligonucleotide-functionalized gold nanostructures have been designed to enter cancer cells without the use of a cationic cocarrier after having been functionalized with a synthetic miR sequence. The prototype of the miR mimic-gold nanoparticle construct consists of a 1-15 nm gold nanoparticle, which was functionalized with a monolayer of a double-stranded alkylthiol-modified RNA molecule of around 30 duplexes. ${ }^{123}$ Hao et al further proved that a gold nanostructure could carry the mimics of miR-205, which are known to have a tumor suppressive effect, thus inhibiting cancer cell proliferation and migration. ${ }^{123}$

\section{miRNA-based therapy}

miRNAs are able to modulate different pathways, ${ }^{124,125}$ taking into account that a single miRNA is able to target multiple genes. Various approaches were applied to assess the significance of a particular miRNA or distinct representatives from a miRNA family, while noting that miRNAs from the same family could have antagonistic biological effects. ${ }^{126,127}$ There is increasing evidence that attempts to explain the miRNA's observed correlation with drug sensitivity. ${ }^{128-130}$

The practical implication of miRNAs in the initiation, development, and progression of cancer has led to the buildup of novel therapeutic schemes. Approaches include, among others, the inhibition of upregulated miRNAs (oncogenic role), as well as using miRNA replacement therapy by restoring the normal levels of tumor supressors miRNA. Oncogenic 
miRNAs are inhibited based on antisense oligonucleotides, antagomirs, sponges, or locked nucleic acid structures. ${ }^{118}$ Additional approaches involve the restoration of tumor suppressor miRNA expression using miRNA mimics, based on viral or nonviral delivery systems. Both approaches have showcased favorable outcomes in preclinical and clinical studies. ${ }^{118}$

Considering the significance of miRNAs in cancer and its capacity to modulate various biological pathways, miRNA mimics/inhibition asserted a new and effective therapeutic strategy in cancer. ${ }^{1,2,118}$ Specifically, miRNAs or antimiRNA may be used individually or in combination with chemotherapy, leading to an enhanced therapeutic response and to an improved survival rate. ${ }^{131}$ In order to apply the vast potential of miRNAs for therapy, the main obstacle for the successful translation of therapeutic strategies into the clinic remains the pathway of delivery. ${ }^{132}$
miRNA expression patterns can be altered by various mechanisms, including genetic and epigenetic alterations. ${ }^{133}$ Correlations between miRNA expression and chromosomal abnormalities were shown to be involved in the pathogenesis of chronic lymphocytic leukemia, since miRNAs are involved in the initiation, prognosis, and chemoresistance of chronic lymphocytic leukemia. ${ }^{134-136}$ Concomitantly, the inhibition of the oncogenic miR-21 with antisense oligonucleotides generates a proapoptotic and antiproliferative response in vitro in different cell models, reducing tumor development and metastatic potential in vivo. ${ }^{118}$ Other examples are presented in Table 1.

\section{Clinical implications in hematology and oncology}

Nanotechnology is of major interest in clinical hematology and oncology for both therapy and diagnosis because of their

Table I Examples of miRNA therapeutic implications in hematological malignancies

\begin{tabular}{|c|c|c|c|c|}
\hline Hematological disease & Study model & Target miRNA & Biological effect & Reference \\
\hline MCL & $\begin{array}{l}\text { MCL cell line; xenograft } M C L \\
\text { mouse model }\end{array}$ & miR-17-92 cluster & $\begin{array}{l}\text { Protein phosphatase PHLPP2, } \\
\text { a key negative regulator of the } \\
\text { PI3K/AKT pathway, being a target } \\
\text { of miR-I7-92 }\end{array}$ & $118,137,138$ \\
\hline \multirow[t]{4}{*}{ AML } & OCl-AML3 and Molm I 3 & let-7a & $\begin{array}{l}\text { CXCR4 regulates let-7a expression } \\
\text { via } Y Y I \text {, leading to the activation } \\
\text { of } M Y C \text { and } B C L X L \text { in } A M L \text { cells }\end{array}$ & 139 \\
\hline & AML versus healthy individuals & miR-22I/222 & $\begin{array}{l}\text { miR-22I/222 can be considered } \\
\text { a marker of disease progression } \\
\text { and an important therapeutic target }\end{array}$ & 140 \\
\hline & $\begin{array}{l}\text { AML cell lines, mouse models, } \\
\text { and primary samples }\end{array}$ & Mir-29 & $\begin{array}{l}\text { Target apoptosis, cell cycle, } \\
\text { and proliferation pathways; reduce } \\
\text { tumorigenesis }\end{array}$ & $14 \mid$ \\
\hline & AML versus healthy individuals & miR-I55 & $\begin{array}{l}\text { miR-I55 upregulation identifies } \\
\text { high-risk patients }\end{array}$ & 142 \\
\hline ALL & Reh cells, ALL primary cells & $\begin{array}{l}\text { MiR-I25b, miR-100, } \\
\text { and miR-99a }\end{array}$ & $\begin{array}{l}\text { Coregulate vincristine resistance } \\
\text { in childhood ALL }\end{array}$ & 143 \\
\hline \multirow[t]{2}{*}{ CLL } & $\begin{array}{l}\text { MEG-0I cells; tumor xenografts } \\
\text { of leukemic cells in nude mice } \\
\text { and in primary CLL samples }\end{array}$ & miR-I5 and miR-I6 & $\begin{array}{l}\text { miR-I5 and miR-16 induce } \\
\text { apoptosis by targeting BCL2 }\end{array}$ & 144 \\
\hline & CLL samples in animal models & miR-29 and miR-I8I & $\begin{array}{l}\text { miR-29 and miR-I8I are inversely } \\
\text { correlated with } T C L I \text { expression }\end{array}$ & 145 \\
\hline \multirow[t]{3}{*}{ CML } & $\begin{array}{l}\text { Imatinib-resistant versus } \\
\text { imatinib-responsive patients }\end{array}$ & miR-I8Ic & $\begin{array}{l}\text { miR-I8Ic target genes like } P B X 3 \text {, } \\
H S P 90 B I, N M T 2 \text {, and } R A D 2 I \text { were } \\
\text { correlated with drug response }\end{array}$ & 146 \\
\hline & $\begin{array}{l}\text { K562 cells, CML patients } \\
\text { versus healthy individuals }\end{array}$ & miR-196b & $\begin{array}{l}\text { miR-196b downregulation increase } \\
\text { the expression of } B C R-A B L I \\
\text { and HOXA9 oncogenes }\end{array}$ & 147 \\
\hline & $\begin{array}{l}\text { K562 cells, CML patients } \\
\text { versus healthy individuals }\end{array}$ & mRNA-30a & $\begin{array}{l}\text { mRNA-30a downregulation } \\
\text { leads to increased } A B L I \text { and } \\
B C R-A B L I \text { expression }\end{array}$ & 148 \\
\hline
\end{tabular}

Abbreviations: miRNA, micro ribonucleic acid; MCL, mantle cell lymphoma; PI3K, phosphoinositide 3-kinase; AML, acute myeloid leukemia; CXCR4, chemokine receptor type 4; MYC, myelocytomatosis oncogene; BCLXL, B-cell lymphoma-extra large; ALL, acute lymphoblastic leukemia; CLL, chronic lymphocytic leukemia; MEG-0I, maternaleffect germ; BCL2, B-cell lymphoma 2; CML, chronic myeloid leukemia. 
unique features. These include self-assembly or the ability to make use of the enhanced permeability and retention capacity that most malignancies have as a consequence of leaky neoangiogenesis and the absence of a functional lymphatic system. ${ }^{149}$ Nanostructures (Table 2) can also be designed to carry useful payloads that include low molecular weight chemotherapy agents or contrast agents. ${ }^{150,151}$ Moreover, the newly formed structures are able to rapidly detect cancer cells, load multiple anticancer agents on their surface, and deliver the drugs rapidly at the target cell, ${ }^{152-154}$ while preventing their bioactive cargo degradation when the investigator chooses to use an RNA-based approach.

Non-Hodgkin's lymphomas are the most common lymphohematopoietic malignancies both in the US and in Europe. ${ }^{166}$ One particular type is anaplastic lymphoma kinase (ALK)-positive anaplastic large cell lymphoma, which is a very aggressive T-cell lymphoma with an abnormal expression of both the $A L K$ oncogene, as well as the surface protein, CD30. ${ }^{167-169}$ A nucleic acid-based knockdown of $A L K$ gene expression has been proven to promote cell death of the malignant T-cell. ${ }^{170,171}$ Mori et al ${ }^{172}$ have developed an RNA aptamer that specifically binds to the CD30 epitope. Zhao et al ${ }^{173}$ have subsequently hypothesized that a lymphoma cell-selective delivery of a tumor gene-specific siRNA could be achieved by assembling a functional RNA nanocomplex comprising the CD30-specific aptamer and the ALK-targeted siRNA, all within a nanosized PEG-based polymer carrier. PEG-based structures are considered to be rather safe, as toxicity assays done using BALB/c mice showed little or no side effects, except for $40 \%$ accumulation in the liver. ${ }^{174}$ This new approach proved that the nanocomplex could be cancer cell-selective and cancer gene-specific, with great potential in the clinic if hepatic damage can be avoided.

Another non-Hodgkin's lymphoma with a very aggressive behavior and short-term survival is mantle cell lymphoma.
This particular type of malignancy is resistant to most therapeutic approaches, including immunochemotherapy and stem cell transplantation, leading investigators to look for different salvage treatment options. ${ }^{175-178}$ SYK is a new target for the management of B-lineage leukemias and lymphomas, ${ }^{179}$ as it regulates apoptosis by controlling activation of the phosphoinositide 3-kinase/AKT, nuclear factor-kappa B, and signal transducer and activator of transcription 3 pathways, which are all very important in the signaling of the stem cell lineage. ${ }^{180,181}$ Cely et al ${ }^{182}$ reported a different approach by developing a nanotechnology-based platform that can be used to target a very selective SYK inhibitor for the lymphoma cell. The designed liposomal nanoparticle was the pentapeptide mimic, 1,4-bis(9-O-dihydroquinidinyl)phthalazine/ hydroquinidine 1,4-phathalazinediyl diether (C16). The liposomal nanoparticle of $\mathrm{C} 16$ was shown to induce apoptosis of the lymphoma cell after 24 hours, providing the scientific background for an alternative treatment for refractory mantle cell lymphoma. ${ }^{182}$ However, previous experience using liposomes shows that this treatment strategy is accompanied by several side effects. For patients with AIDS-related Kaposi's sarcoma, $30 \%$ of those treated with Doxil presented with low blood counts and palmar-plantar erythrodysethesia, ${ }^{183,184}$ yet the clinicians easily managed these symptoms.

Carbon nanotubes are tubes made out of graphic carbon that have very good mechanical strength, good flexibility, and excellent thermal and electrical conductivity, ${ }^{185-187}$ qualities that initially made them suitable candidates for novel drug design. These tubes have been conjugated with monoclonal antibodies and plasmid deoxyribonucleic acid (DNA) in order to achieve cancer cell inhibition, ${ }^{188-191}$ and conjugates have also been made with paclitaxel and other cytostatics. ${ }^{192}$ Liu et al inhibited the growth of breast cancer by conjugating carbon nanotubes with paclitaxel, and they showed that the intravenous administration of $10 \mathrm{mg} / \mathrm{kg}$ of the new com-

Table 2 Various nanostructures used in translational cancer research

\begin{tabular}{|c|c|c|c|c|}
\hline Disease & Nanostructure & Active agent & Biological effect & Reference \\
\hline Kaposi sarcoma & Liposomes & Doxorubicin & Cytostatic & 155 \\
\hline Colorectal cancer & Carbon nanotubes & Anti-EGFR antibody & Cytostatic & 156 \\
\hline Melanoma & Carbon nanotubes & Hematoporphyrin monomethyl ether & Photodynamic therapy & 157 \\
\hline Malignant gliomas & Carbon nanotubes & Tumor lysate & Vaccination & 158 \\
\hline Breast cancer & Carbon nanotubes & Paclitaxel & Cytostatic & 159 \\
\hline Pancreatic cancer & Gold nanoparticles & Bortezomib & Cytostatic & 160 \\
\hline Breast cancer & Gold nanoparticles & Gadolinium chelate & Diagnostics & 161 \\
\hline Neuroblastoma & Gold nanoparticles & Barium titanate & Photothermal therapy & 162 \\
\hline Hepatocellular carcinoma & Silver nanoparticles & Protein conjugate silver sulfide & Cytostatic & 163 \\
\hline Breast cancer & Quantum dots & Mortalin antibody & Diagnostics & 164 \\
\hline Lung cancer & Quantum dots & CdTE: $\mathrm{Zn}^{2+}$ & Diagnostics & 165 \\
\hline
\end{tabular}

Abbreviation: EGFR, epidermal growth factor receptor. 
pound enhanced the therapeutic efficacy when compared with doxorubicin-free treated mice. ${ }^{104}$ Still, because of their fiber shape and size, carbon nanotubes cause cytotoxicity, inflammation, and DNA damage in vitro. ${ }^{193-196}$ The animal models used to study the toxic effects of carbon nanotubes demonstrated that the high concentrations needed to induce the regression of the tumor may cause chronic lung inflammation, foreign-body granulomas, or interstitial fibrosis, ${ }^{197-200}$ limiting their potential clinical use.

Other types of nanoparticles with biomedical application are metallic colloidal gold and silver. ${ }^{201-206}$ These structures are used for photothermal ablation therapy, as well as for contrast enhancers in computed tomography or X-ray diagnostics. ${ }^{207,208}$ Niidome et al ${ }^{202}$ have reported no toxicity in their studies in a mouse model of colon adenocarcinoma after having used intravenous PEG-coated nanorods, in spite of the fact that gold may interact with intracellular proteins and modify their structure, causing autoimmune-related toxicity. Silver nanostructures are commercially available for antimicrobial use, ${ }^{209,210}$ yet recent data show that silver oxide may also be used in cancer research, as the nanostructure cargo can induce the regression of cancer neoangiogenesis. ${ }^{211-214}$ Still, toxicity limits their use because silver nanoparticles can cause destruction of the blood-brain barrier, brain degeneration, and edema, ${ }^{215-217}$ as well as liver failure. ${ }^{218}$

Diagnostics can also be aided based on diffident nanostructures types including quantum dots or metallic coreshell nanoparticles that usually contain cadmium telluride, cadmium selenide, and either indium arsenide or indium phosphide. ${ }^{1,2}$ This structure is then covered by a shell of zinc sulfide and is subsequently coated with PEG in order to facilitate the attachment of various drugs, nucleic acids, or antibodies. ${ }^{219-221}$ These structures are very good fluorophores because of their broad-spectrum fluorescence, ${ }^{222}$ and they can be used to properly identify cancer cells, as well as signal events such as peroxisome activity or the presence of certain membrane receptors. ${ }^{223-226}$ Toxicity in clinical use is not known in great detail, but it seems that following the removal of the coating after their exposure to oxidative environments such as the endosome, ${ }^{227-229}$ quantum dots may be very toxic, which may limit their clinical use (Figure 3).

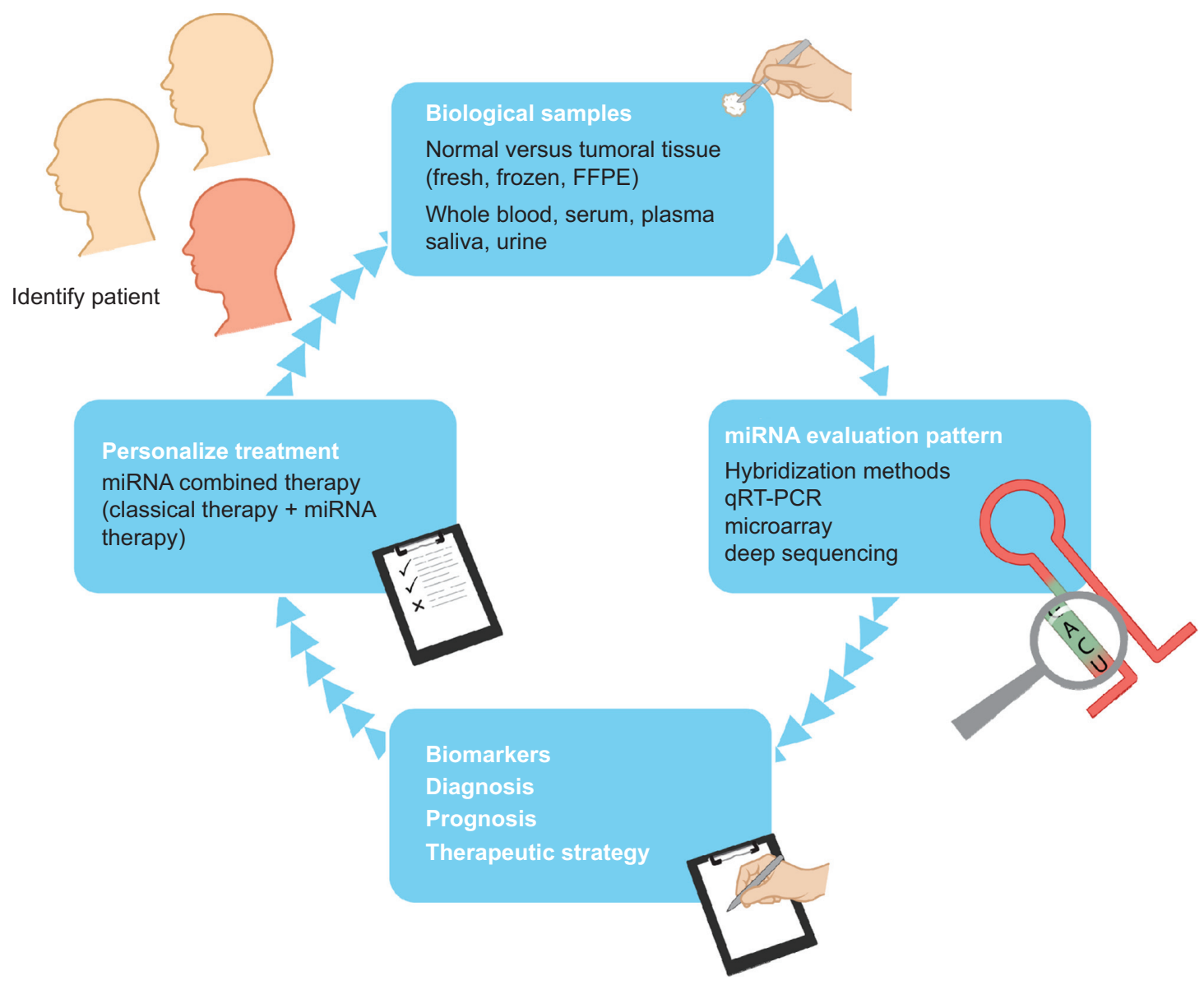

Figure 3 Bench-to-bedside evolution in translational hematology and oncology.

Abbreviations: FFPE, formalin-fixed, paraffin-embedded; miRNA, micro ribonucleic acid; qRT-PCR, quantitative real-time polymerase chain reaction. 


\section{Conclusion}

In recent years, important progress has been made in nanotechnology, with its ever-increasing applicability in basic and translational medicine, leading to the appearance of a new field known as nanomedicine. This new science deals with the engineering of various structures of nanoscale dimensions that can be properly conjugated with various highly specific targeting agents in order to be used in the clinic, for either early diagnostic purposes or for disease treatment. ${ }^{1,2}$

These endeavors are possible because nanoparticles have unique properties, such as a preferential accumulation in the neoplastic tissue in comparison with healthy cells. ${ }^{1,2}$ These particles hold great potential for possibly replacing current active agents, which have been shown to be highly inefficient, based on epigenetics and molecular pharmacology principles. This step in clinical oncology and hematology is, however, still far from being implemented in clinical practice. Nevertheless, with each experimental report, we come closer to a patient-tailored approach in order to achieve maximum anticancer effects with minimal side effects.

\section{Acknowledgments}

The study was partially financed by a POSCCE grant (709/2010) titled, "Clinical and Economical Impact of Proteome and Transcriptome Molecular Profiling in Neoadjuvant Therapy of Triple Negative Breast Cancer (BREASTIMPACT)", and by an international grant, Romania-European Economical Space (Norway), which was awarded to Ciprian Tomuleasa (contract 1/16.01.2014). Ciprian Tomuleasa's work was financed by an internal grant of the Iuliu Hatieganu University of Medicine and Pharmacy awarded to contract 1492/1/28.01.2014, and Cornelia Braicu's work was supported by a National Fellowship Program, UNESCO L'Oréal "For women in science".

\section{Disclosure}

The authors report no conflicts of interest in this work.

\section{References}

1. de Morais MG, Martins VG, Steffens D, Pranke P, da Costa JA. Biological applications of nanobiotechnology. J Nanosci Nanotechnol. 2014;14(1):1007-1017.

2. Liang XJ. Nanotechnology and cancer nanomedicine. Biotechnol Adv. 2014;32(4):665.

3. Selvamuthukumar S, Velmurugan R. Nanostructured lipid carriers: a potential drug carrier for cancer chemotherapy. Lipids Health Dis. 2012;11:159.

4. Singh S, Sharma A, Robertson GP. Realizing the clinical potential of cancer nanotechnology by minimizing toxicologic and targeted delivery concerns. Cancer Res. 2012;72(22):5663-5668.

5. Orza A, Soriţău O, Tomuleasa C, et al. Reversing chemoresistance of malignant glioma stem cells using gold nanoparticles. Int J Nanomedicine. 2013;8:689-702.
6. Tomuleasa C, Soritau O, Orza A, et al. Gold nanoparticles conjugated with cisplatin/doxorubicin/capecitabine lower the chemoresistance of hepatocellular carcinoma-derived cancer cells. J Gastrointestin Liver Dis. 2012;21(2):187-196.

7. Rotello V. Sniffing out cancer using "chemical nose" sensors. Cell Cycle. 2009;8(22):3615-3616.

8. You CC, Miranda OR, Gider B, et al. Detection and identification of proteins using nanoparticle-fluorescent polymer 'chemical nose' sensors. Nat Nanotechnol. 2007;2(5):318-323.

9. Leonard RC, Williams S, Tulpule A, Levine AM, Oliveros S. Improving the therapeutic index of anthracycline chemotherapy: focus on liposomal doxorubicin (Myocet). Breast. 2009;18(4):218-224.

10. Petrelli F, Borgonovo K, Barni S. Targeted delivery for breast cancer therapy: the history of nanoparticle-albumin-bound paclitaxel. Expert Opin Pharmacother. 2010;11(8):1413-1432.

11. Braicu C, Gherman CD, Irimie A, Berindan-Neagoe I. Epigallocatechin3-Gallate (EGCG) inhibits cell proliferation and migratory behaviour of triple negative breast cancer cells. J Nanosci Nanotechnol. 2013;13(1): 632-637.

12. Neagoe IB, Braicu C, Matea C, et al. Efficient siRNA delivery system using carboxilated single-wall carbon nanotubes in cancer treatment. J Biomed Nanotechnol. 2012;8(4):567-574.

13. Shang L, Nienhaus K, Nienhaus GU. Engineered nanoparticles interacting with cells: size matters. J Nanobiotechnology. 2014;12:5.

14. Juliano RL, Ming X, Nakagawa O. Cellular uptake and intracellular trafficking of antisense and siRNA oligonucleotides. Bioconjug Chem. 2012;23(2):147-157.

15. Del Burgo LS, Pedraz JL, Orive. Advanced nanovehicles for cancer management. Drug Discov Today. In press 2014.

16. Basha R, Sabnis N, Heym K, Bowman WP, Lacko AG. Targeted nanoparticles for pediatric leukemia therapy. Front Oncol. 2014;4:101.

17. Singh R, Mukhopadhyay K. Survival analysis in clinical trials: Basics and must know areas. Perspect Clin Res. 2011;2(4):145-148.

18. Minko T, Rodriguez-Rodriguez L, Pozharov V. Nanotechnology approaches for personalized treatment of multidrug resistant cancers. Adv Drug Deliv Rev. 2013;65(13-14):1880-1895.

19. Hede S, Huilgol N. "Nano": the new nemesis of cancer. J Cancer Res Ther. 2006;2(4):186-195.

20. Panchapakesan B, Wickstrom E. Nanotechnology for sensing, imaging, and treating cancer. Surg Oncol Clin N Am. 2007;16(2):293-305.

21. Thornton G. Materials Science. Watching nanoparticles grow. Science. 2003;300(5624):1378-1379.

22. Moghimi SM, Hunter AC, Murray JC. Nanomedicine: current status and future prospects. FASEB J. 2005;19(3):311-330.

23. Upreti M, Jyoti A, Sethi P. Tumor microenvironment and nanotherapeutics. Transl Cancer Res. 2013;2(4):309-319.

24. Davis ME, Chen ZG, Shin DM. Nanoparticle therapeutics: an emerging treatment modality for cancer. Nat Rev Drug Discov. 2008;7(9): $771-782$.

25. Kopecek J, Kopecková P, Minko T, Lu ZR, Peterson CM. Water soluble polymers in tumor targeted delivery. J Control Release. 2001; 74(1-3):147-158.

26. Shen F, Chu S, Bence AK, et al. Quantitation of doxorubicin uptake, efflux, and modulation of multidrug resistance (MDR) in MDR human cancer cells. J Pharmacol Exp Ther. 2008;324(1):95-102.

27. Park JW, Hong K, Kirpotin DB, et al. Anti-HER2 immunoliposomes: enhanced efficacy attributable to targeted delivery. Clin Cancer Res. 2002;8(4):1172-1181.

28. Yu B, Mao Y, Yuan Y, et al. Targeted drug delivery and cross-linking induced apoptosis with anti-CD37 based dual-ligand immunoliposomes in B chronic lymphocytic leukemia cells. Biomaterials. 2013;34(26): 6185-6193.

29. Lin Y, Pan Y, Shi Y, Huang X, Jia N, Jiang JY. Delivery of large molecules via poly(butyl cyanoacrylate) nanoparticles into the injured rat brain. Nanotechnology. 2012;23(16):165101.

30. Duan J, Mansour HM, Zhang Y, et al. Reversion of multidrug resistance by co-encapsulation of doxorubicin and curcumin in chitosan/poly(butyl cyanoacrylate) nanoparticles. Int J Pharm. 2012;426(1-2): 193-201. 
31. Shen JM, Gao FY, Yin T, et al. cRGD-functionalized polymeric magnetic nanoparticles as a dual-drug delivery system for safe targeted cancer therapy. Pharmacol Res. 2013;70(1):102-115.

32. Shen JM, Guan XM, Liu XY, Lan JF, Cheng T, Zhang HX. Luminescent/ magnetic hybrid nanoparticles with folate-conjugated peptide composites for tumor-targeted drug delivery. Bioconjug Chem. 2012;23(5): 1010-1021.

33. Shen JM, Yin T, Tian XZ, Gao FY, Xu S. Surface charge-switchable polymeric magnetic nanoparticles for the controlled release of anticancer drug. ACS Appl Mater Interfaces. 2013;5(15):7014-7024.

34. Miklášová N, Fischer-Fodor E, Lönnecke P, et al. Antiproliferative effect of novel platinum (II) and palladium (II) complexes on hepatic tumor stem cells in vitro. Eur J Med Chem. 2012;49:41-47.

35. Florian IS, Tomuleasa C, Soritau O, et al. Cancer stem cells and malignant gliomas. From pathophysiology to targeted molecular therapy. $J$ BUON. 2011;16(1):16-23.

36. Tomuleasa C, Soritau O, Rus-Ciuca D, et al. Functional and molecular characterization of glioblastoma multiforme-derived cancer stem cells. J BUON. 2010;15(3):583-591.

37. Ozeki T, Kaneko D, Hashizawa K, Imai Y, Tagami T, Okada H. Combination therapy of surgical tumor resection with implantation of a hydrogel containing camptothecin-loaded poly(lactic-co-glycolic acid) microspheres in a C6 rat glioma model. Biol Pharm Bull. 2012;35(4): 545-550.

38. Ozeki T, Hashizawa K, Kaneko D, Imai Y, Okada H. Treatment of rat brain tumors using sustained-release of camptothecin from poly(lacticco-glycolic acid) microspheres in a thermoreversible hydrogel. Chem Pharm Bull (Tokyo). 2010;58(9):1142-1147.

39. Arai T, Joki T, Akiyama M, et al. Novel drug delivery system using thermoreversible gelation polymer for malignant glioma. J Neurooncol. 2006;77(1):9-15.

40. Devalapally H, Duan Z, Seiden MV, Amiji MM. Modulation of drug resistance in ovarian adenocarcinoma by enhancing intracellular ceramide using tamoxifen-loaded biodegradable polymeric nanoparticles. Clin Cancer Res. 2008;14(10):3193-3203.

41. Raimundo K, Biskupiak J, Goodman M, Silverstein S, Asche C. Cost effectiveness of liposomal doxorubicin vs. paclitaxel for the treatment of advanced AIDS-Kaposi's sarcoma. J Med Econ 2013;16(5):606-613.

42. Thierry AR, Vigé D, Coughlin SS, Belli JA, Dritschilo A, Rahman A. Modulation of doxorubicin resistance in multidrug-resistant cells by liposomes. FASEB J. 1993;7(6):572-579.

43. Bitounis D, Fanciullino R, Iliadis A, Ciccolini J. Optimizing druggability through liposomal formulations: new approaches to an old concept. ISRN Pharm. 2012;2012:738432.

44. Klibanov AL, Maruyama K, Torchilin VP, Huang L. Amphipathic polyethyleneglycols effectively prolong the circulation time of liposomes. FEBS Lett. 1990;268(1):235-237.

45. Maruyama K, Yuda T, Okamoto A, Kojima S, Suginaka A, Iwatsuru M. Prolonged circulation time in vivo of large unilamellar liposomes composed of distearoyl phosphatidylcholine and cholesterol containing amphipathic poly(ethylene glycol). Biochim Biophys Acta. 1992;1128(1):44-49.

46. Papahadjopoulos D, Allen TM, Gabizon A, et al. Sterically stabilized liposomes: improvements in pharmacokinetics and antitumor therapeutic efficacy. Proc Natl Acad Sci U S A. 1991;88(24): 11460-11464.

47. Uster PS, Allen TM, Daniel BE, Mendez CJ, Newman MS, Zhu GZ. Insertion of poly(ethylene glycol) derivatized phospholipid into preformed liposomes results in prolonged in vivo circulation time. FEBS Lett. 1996;386(2-3):243-246.

48. Hatakeyama H, Akita H, Harashima H. The polyethyleneglycol dilemma: advantage and disadvantage of PEGylation of liposomes for systemic genes and nucleic acids delivery to tumors. Biol Pharm Bull. 2013;36(6):892-899.

49. Mooberry LK, Nair M, Paranjape S, McConathy WJ, Lacko AG. Receptor mediated uptake of paclitaxel from a synthetic high density lipoprotein nanocarrier. J Drug Target. 2010;18(1):53-58.
50. Bhattacharya R, Mukherjee P. Biological properties of "naked" metal nanoparticles. Adv Drug Deliv Rev. 2008;60(11):1289-1306.

51. Oraki Kohshour M, Mirzaie S, Zeinali M, et al. Ablation of breast cancer cells using trastuzumab-functionalized multi-walled carbon nanotubes and trastuzumab-diphtheria toxin conjugate. Chem Biol Drug Des. 2014;83(3):259-265.

52. Manjappa AS, Goel PN, Vekataraju MP, et al. Is an alternative drug delivery system needed for docetaxel? The role of controlling epimerization in formulations and beyond. Pharm Res. 2013;30(10):2675-2693.

53. Seo YG, Kim DH, Ramasamy T, et al. Development of docetaxelloaded solid self-nanoemulsifying drug delivery system (SNEDDS) for enhanced chemotherapeutic effect. Int J Pharm. 2013;452(1-2): $412-420$.

54. Templeton AC, Wuelfing WP, Murray RW. Monolayer-protected cluster molecules. Acc Chem Res. 2000;33(1):27-36.

55. Connor EE, Mwamuka J, Gole A, Murphy CJ, Wyatt MD. Gold nanoparticles are taken up by human cells but do not cause acute cytotoxicity. Small. 2005;1(3):325-327.

56. Boca SC, Potara M, Gabudean AM, Juhem A, Baldeck PL, Astilean S. Chitosan-coated triangular silver nanoparticles as a novel class of biocompatible, highly effective photothermal transducers for in vitro cancer cell therapy. Cancer Lett. 2011;311(2):131-140.

57. Suarasan S, Focsan M, Maniu D, Astilean S. Gelatin-nanogold bioconjugates as effective plasmonic platforms for SERS detection and tagging. Colloids Surf B Biointerfaces. 2013;103:475-481.

58. Gabudean AM, Biro D, Astilean S. Hybrid plasmonic platforms based on silica-encapsulated gold nanorods as effective spectroscopic enhancers for Raman and fluorescence spectroscopy. Nanotechnology. 2012;23(48):485706.

59. Focsan M, Ardelean II, Craciun C, Astilean S. Interplay between gold nanoparticle biosynthesis and metabolic activity of cyanobacterium Synechocystis sp. PCC 6803. Nanotechnology. 2011;22(48): 485101.

60. Potara M, Maniu D, Astilean S. The synthesis of biocompatible and SERS-active gold nanoparticles using chitosan. Nanotechnology. 2009;20(31):315602.

61. Boca SC, Astilean S. Detoxification of gold nanorods by conjugation with thiolated poly(ethylene glycol) and their assessment as SERS-active carriers of Raman tags. Nanotechnology. 2010;21(23): 235601.

62. Aldea MD, Petrushev B, Soritau O, et al. Metformin plus sorafenib highly impacts temozolomideresistant glioblastoma stem-like cells. J BUON. 2014;19(2):502-11.

63. Xi G, Robinson E, Mania-Farnell B, et al. Convection-enhanced delivery of nanodiamond drug delivery platforms for intracranial tumor treatment. Nanomedicine. 2014;10(2):381-391.

64. Man HB, Kim H, Kim HJ, et al. Synthesis of nanodiamond-daunorubicin conjugates to overcome multidrug chemoresistance in leukemia. Nanomedicine. 2014;10(2):359-369.

65. Cirpanli Y, Bilensoy E, Lale Doğan A, Caliş S. Comparative evaluation of polymeric and amphiphilic cyclodextrin nanoparticles for effective camptothecin delivery. Eur J Pharm Biopharm. 2009;73(1):82-89.

66. Soukasene S, Toft DJ, Moyer TJ, et al. Antitumor activity of peptide amphiphile nanofiber-encapsulated camptothecin. ACS Nano. 2011; 5(11):9113-9121.

67. Min KH, Park K, Kim YS, et al. Hydrophobically modified glycol chitosan nanoparticles-encapsulated camptothecin enhance the drug stability and tumor targeting in cancer therapy. $J$ Control Release. 2008;127(3):208-218

68. Barua S, Yoo JW, Kolhar P, Wakankar A, Gokarn YR, Mitragotri S. Particle shape enhances specificity of antibody-displaying nanoparticles. Proc Natl Acad Sci U S A. 2013;110(9):3270-3275.

69. Ni G, Wang Y, Wu X, Wang X, Chen S, Liu X. Graphene oxide absorbed anti-IL10R antibodies enhance LPS induced immune responses in vitro and in vivo. Immunol Lett. 2012;148(2):126-132.

70. Jaganathan H, Mitra S, Srinivasan S, Dave B, Godin B. Design and in vitro evaluation of layer by layer siRNA nanovectors targeting breast tumor initiating cells. PLoS One. 2014 Apr 2;9(4):e91986. 
71. Davis ME. The first targeted delivery of siRNA in humans via a selfassembling, cyclodextrin polymer-based nanoparticle: from concept to clinic. Mol Pharm. 2009;6(3):659-668.

72. van Vlerken LE, Amiji MM. Multi-functional polymeric nanoparticles for tumour-targeted drug delivery. Expert Opin Drug Deliv. 2006;3(2):205-216.

73. Sun C, Sze R, Zhang M. Folic acid-PEG conjugated superparamagnetic nanoparticles for targeted cellular uptake and detection by MRI. J Biomed Mater Res A. 2006;78(3):550-557.

74. Medarova Z, Pham W, Farrar C, Petkova V, Moore A. In vivo imaging of siRNA delivery and silencing in tumors. Nat Med. 2007;13(3): $372-377$.

75. Gunn J, Wallen H, Veiseh O, et al. A multimodal targeting nanoparticle for selectively labeling T cells. Small. 2008;4(6):712-715.

76. Veiseh O, Kievit FM, Gunn JW, Ratner BD, Zhang M. A ligandmediated nanovector for targeted gene delivery and transfection in cancer cells. Biomaterials. 2009;30(4):649-657.

77. Lewin M, Carlesso N, Tung CH, et al. Tat peptide-derivatized magnetic nanoparticles allow in vivo tracking and recovery of progenitor cells. Nat Biotechnol. 2000;18(4):410-414.

78. Harisinghani MG, Barentsz J, Hahn PF, et al. Noninvasive detection of clinically occult lymph-node metastases in prostate cancer. $N$ Engl J Med. 2003;348(25):2491-2499.

79. Wadajkar AS, Menon JU, Kadapure T, Tran RT, Yang J, Nguyen KT. Design and application of magnetic-based theranostic nanoparticle systems. Recent Pat Biomed Eng. 2013;6(1):47-57.

80. Vlasova MA, Rytkönen J, Riikonen J, et al. Nanocarriers and the delivered drug: Effect interference due to intravenous administration. Eur J Pharm Sci. In press 2014

81. Babincová M, Kontrisova K, Durdík S, Bergemann C, Sourivong P. Radiation enhanced efficiency of combined electromagnetic hyperthermia and chemotherapy of lung carcinoma using cisplatin functionalized magnetic nanoparticles. Pharmazie. 2014;69(2):128-131.

82. Chanda N, Kan P, Watkinson LD, et al. Radioactive gold nanoparticles in cancer therapy: therapeutic efficacy studies of GA-198AuNP nanoconstruct in prostate tumor-bearing mice. Nanomedicine. 2010;6(2): 201-209.

83. Garrison JC, Rold TL, Sieckman GL, et al. In vivo evaluation and small-animal PET/CT of a prostate cancer mouse model using $64 \mathrm{Cu}$ bombesin analogs: side-by-side comparison of the CB-TE2A and DOTA chelation systems. J Nucl Med. 2007;48(8):1327-1337.

84. El-Aneed A. An overview of current delivery systems in cancer gene therapy. J Control Release. 2004;94(1):1-14.

85. Mintzer MA, Simanek EE. Nonviral vectors for gene delivery. Chem Rev. 2009;109(2):259-302.

86. Boussif O, Lezoualc'h F, Zanta MA, et al. A versatile vector for gene and oligonucleotide transfer into cells in culture and in vivo: polyethylenimine. Proc Natl Acad Sci U S A. 1995;92(16): 7297-7301.

87. Swami A, Goyal R, Tripathi SK, et al. Effect of homobifunctional crosslinkers on nucleic acids delivery ability of PEI nanoparticles. Int J Pharm. 2009;374(1-2):125-138.

88. Oh YK, Suh D, Kim JM, Choi HG, Shin K, Ko JJ. Polyethyleniminemediated cellular uptake, nucleus trafficking and expression of cytokine plasmid DNA. Gene Ther. 2002;9(23):1627-1632.

89. Xu P, Li SY, Li Q, et al. Biodegradable cationic polyester as an efficient carrier for gene delivery to neonatal cardiomyocytes. Biotechnol Bioeng. 2006;95(5):893-903.

90. Florea BI, Meaney C, Junginger HE, Borchard G. Transfection efficiency and toxicity of polyethylenimine in differentiated Calu-3 and nondifferentiated COS-1 cell cultures. AAPS Pharm Sci. 2002; 4(3):E12.

91. Ellington AD, Szostak JW. In vitro selection of RNA molecules that bind specific ligands. Nature. 1990;346(6287):818-822.

92. Tuerk C, Gold L. Systematic evolution of ligands by exponential enrichment: RNA ligands to bacteriophage T4 DNA polymerase. Science. 1990;249(4968):505-510.
93. Jenison RD, Gill SC, Pardi A, Polisky B. High-resolution molecular discrimination by RNA. Science. 1994;263(5152):1425-1429.

94. Lee Y, Miyata K, Oba M, et al. Charge-conversion ternary polyplex with endosome disruption moiety: a technique for efficient and safe gene delivery. Angew Chem Int Ed Engl. 2008;47(28): 5163-5166.

95. Xu P, Van Kirk EA, Zhan Y, Murdoch WJ, Radosz M, Shen Y. Targeted charge-reversal nanoparticles for nuclear drug delivery. Angew Chem Int Ed Engl. 2007;46(26):4999-5002.

96. Shen Y,ZhouZ, Sui M, et al. Charge-reversal polyamidoamine dendrimer for cascade nuclear drug delivery. Nanomedicine (Lond). 2010;5(8): 1205-1217.

97. Rozema DB, Ekena K, Lewis DL, Loomis AG, Wolff JA. Endosomolysis by masking of a membrane-active agent (EMMA) for cytoplasmic release of macromolecules. Bioconjug Chem. 2003;14(1): 51-57.

98. Miyata K, Oba M, Nakanishi M, et al. Polyplexes from poly(aspartamide) bearing 1,2-diaminoethane side chains induce $\mathrm{pH}$-selective, endosomal membrane destabilization with amplified transfection and negligible cytotoxicity. J Am Chem Soc. 2008;130(48):16287-16294.

99. Liu X, Zhang J, Lynn DM. Polyelectrolyte multilayers fabricated from 'charge-shifting' anionic polymers: a new approach to controlled film disruption and the release of cationic agents from surfaces. Soft Matter. 2008;4(8):1688-1695

100. Bao Q, Shi Y. Apoptosome: a platform for the activation of initiator caspases. Cell Death Differ. 2007;14(1):56-65.

101. Manna P, Ghosh M, Ghosh J, Das J, Sil PC. Contribution of nanocopper particles to in vivo liver dysfunction and cellular damage: role of I $\kappa \mathrm{B} \alpha / \mathrm{NF}-\kappa \mathrm{B}, \mathrm{MAPKs}$ and mitochondrial signal. Nanotoxicology. 2012;6(1):1-21.

102. Jeong JH, Park TG. Novel polymer-DNA hybrid polymeric micelles composed of hydrophobic poly(D,L-lactic-co-glycolic acid) and hydrophilic oligonucleotides. Bioconjug Chem. 2011;12(6): 917-923.

103. Kataoka K, Itaka K, Nishiyama N, Yamasaki Y, Oishi M, Nagasaki Y. Smart polymeric micelles as nanocarriers for oligonucleotides and siRNA delivery. Nucleic Acids Symp Ser (Oxf). 2005;(49): $17-18$.

104. Liu J, Lu Y. Fast colorimetric sensing of adenosine and cocaine based on a general sensor design involving aptamers and nanoparticles. Agnew Chem Int Ed Engl. 2005;45(1):90-94.

105. Yang H, Liu H, Kang H, Tan W. Engineering target-responsive hydrogels based on aptamer-target interactions. J Am Chem Soc. 2008; 130(20):6320-6321.

106. Marcus ME, Leonard JN. FedExosomes: engineering therapeutic biological nanoparticles that truly deliver. Pharmaceuticals (Basel). 2013;6(5):659-680.

107. EL Andaloussi S, Mäger I, Breakefield XO, Wood MJ. Extracellular vesicles: biology and emerging therapeutic opportunities. Nat Rev Drug Discov. 2013;12(5):347-357.

108. Kowal J, Tkach M, Théry C. Biogenesis and secretion of exosomes. 2014;29:116-125.

109. Valadi H, Ekström K, Bossios A, Sjöstrand M, Lee JJ, Lötvall JO. Exosome-mediated transfer of mRNAs and microRNAs is a novel mechanism of genetic exchange between cells. Nat Cell Biol. 2007; 9(6):654-659.

110. Nazarenko I, Rupp AK, Altevogt P. Exosomes as a potential tool for a specific delivery of functional molecules. Methods Mol Biol. 2013; 1049:495-511.

111. Tickner JA, Urquhart AJ, Stephenson SA, Richard DJ, O'Byrne KJ. Functions and therapeutic roles of exosomes in cancer. Front Oncol. 2014;4:127.

112. Lehrman S. Virus treatment questioned after gene therapy death. Nature. 1999;401(6753):517-518.

113. Koga K, Matsumoto K, Akiyoshi T, et al. Purification, characterization and biological significance of tumor-derived exosomes. Anticancer Res. 2005;25(6A):3703-3707. 
114. Castanotto D, Rossi JJ. The promises and pitfalls of RNA-interferencebased therapeutics. Nature. 2009;457(7228):426-433.

115. Wahlgren J, De L Karlson T, Brisslert M, et al. Plasma exosomes can deliver exogenous short interfering RNA to monocytes and lymphocytes. Nucleic Acids Res. 2012;40(17):e130.

116. Alvarez-Erviti L, Seow Y, Yin H, Betts C, Lakhal S, Wood MJ. Delivery of siRNA to the mouse brain by systemic injection of targeted exosomes. Nat Biotechnol. 2011;29(4):341-345.

117. El-Andaloussi S, Lee Y, Lakhal-Littleton S, et al. Exosome-mediated delivery of siRNA in vitro and in vivo. Nat Protoc. 2012;7(12): 2112-2126.

118. Braicu C, Calin GA, Berindan-Neagoe I. MicroRNAs and cancer therapy - from bystanders to major players. Curr Med Chem. 2013;20(29):3561-3573.

119. Garzon R, Marcucci G, Croce CM. Targeting microRNAs in cancer: rationale, strategies and challenges. Nat Rev Drug Discov. 2010;9(10): 775-789.

120. Jicha GA, Carr SA. Conceptual Evolution in Alzheimer's Disease: Implications for Understanding the Clinical Phenotype of Progressive Neurodegenerative Disease. J Alzheimers Dis. 2010;19(1): 253-272.

121. Freddi G, Romàn-Pumar JL. Evidence-based medicine: what it can and cannot do. Ann Ist Super Sanita. 2011;47(1):22-25.

122. Singh S, Loke YK. Drug safety assessment in clinical trials: methodological challenges and opportunities. Trials. 2012;13:138.

123. Hao L, Patel PC, Alhasan AH, Giljohann DA, Mirkin CA. Nucleic acid-gold nanoparticle conjugates as mimics of microRNA. Small. 2011;7(22):3158-3162

124. Bhayani MK, Calin GA, Lai SY. Functional relevance of miRNA sequences in human disease. Mutat Res. 2012;731(1-2):14-19.

125. Munker R, Calin GA. MicroRNA profiling in cancer. Clin Sci (Lond). 2011;121(4):141-158.

126. Fabbri M, Calin GA. Epigenetics and miRNAs in human cancer. $A d v$ Genet. 2010;70:87-99.

127. Santarpia L, Nicoloso M, Calin GA. MicroRNAs: a complex regulatory network drives the acquisition of malignant cell phenotype. Endocr Relat Cancer. 2010;17(1):F51-F75.

128. Calin GA, Croce CM. Chronic lymphocytic leukemia: interplay between noncoding RNAs and protein-coding genes. Blood. 2009;114(23): 4761-4770.

129. Garzon R, Calin GA, Croce CM. MicroRNAs in Cancer. Annu Rev Med. 2009;60:167-179.

130. Negrini M, Nicoloso MS, Calin GA. MicroRNAs and cancernew paradigms in molecular oncology. Curr Opin Cell Biol. 2009;21(3): 470-479.

131. Visone R, Croce CM. MiRNAs and cancer. Am J Pathol. 2009;174(4): $1131-1138$

132. Mauritz KH, Peckham HP. Restoration of grasping functions in quadriplegic patients by Functional Electrical Stimulation (FES). Int J Rehabil Res. 1987;10(4 Suppl 5):57-61.

133. Palmero EI, de Campos SG, Campos M, et al. Mechanisms and role of microRNA deregulation in cancer onset and progression. Genet Mol Biol. 2011;34(3):363-370.

134. Zhou XX, Wang X. Role of microRNAs in chronic lymphocytic leukemia (Review). Mol Med Rep. 2013;8(3):719-725.

135. Calin GA, Cimmino A, Fabbri M, et al. MiR-15a and miR-16-1 cluster functions in human leukemia. Proc Natl Acad Sci U S A. 2008;105(13): 5166-5171

136. Rao E, Jiang C, Ji M, et al. The miRNA-17 92 cluster mediates chemoresistance and enhances tumor growth in mantle cell lymphoma via PI3K/AKT pathway activation. Leukemia. 2012;26(5): 1064-1072.

137. Lieberman R, Califano P. Roentgenographic manifestations of gout A case report. J Am Podiatr Med Assoc. 1987;77(9):506-509.

138. Venturini L, Battmer K, Castoldi M, et al. Expression of the miR-17-92 polycistron in chronic myeloid leukemia (CML) CD34+ cells. Blood. 2007;109(10):4399-4405.
139. Rommer A, Steinleitner K, Hackl H, et al. Overexpression of primary microRNA 221/222 in acute myeloid leukemia. BMC Cancer. 2013;13:364.

140. Gimenes-Teixeira HL, Lucena-Araujo AR, Dos Santos GA, et al. Increased expression of miR-221 is associated with shorter overall survival in T-cell acute lymphoid leukemia. Exp Hematol Oncol. 2013;2(1):10

141. Garzon R, Heaphy CE, Havelange V, et al. MicroRNA 29b functions in acute myeloid leukemia. Blood. 2009;114(26):5331-5341.

142. Marcucci G, Maharry KS, Metzeler KH, et al. Clinical role of microRNAs in cytogenetically normal acute myeloid leukemia: miR-155 upregulation independently identifies high-risk patients. J Clin Oncol. 2013;31(17):2086-2093.

143. Akbari Moqadam F, Lange-Turenhout EA, Ariës IM, Pieters R, den Boer ML. MiR-125b, miR-100 and miR-99a co-regulate vincristine resistance in childhood acute lymphoblastic leukemia. Leuk Res. 2013; 37(10):1315-1321.

144. Aqeilan RI, Calin GA, Croce CM. miR-15a and miR-16-1 in cancer: discovery, function and future perspectives. Cell Death Differ. 2010; 17(2):215-220.

145. Pekarsky Y, Santanam U, Cimmino A, et al. Tcl1 expression in chronic lymphocytic leukemia is regulated by miR-29 and miR-181. Cancer Res. 2006;66(24):11590-11593.

146. Mosakhani N, Mustjoki S, Knuutila S. Down-regulation of miR-181c in imatinib-resistant chronic myeloid leukemia. Mol Cytogenet. 2013;6(1):27.

147. Liu Y, Song Y, Ma W, Zheng W, Yin H. Decreased microRNA-30a levels are associated with enhanced ABL1 and BCR-ABL1 expression in chronic myeloid leukemia. Leuk Res. 2013;37(3):349-356.

148. Matsumura Y, Maeda H. A new concept for macromolecular therapeutics in cancer chemotherapy: mechanism of tumoritropic accumulation of proteins and the antitumor agent smancs. Cancer Res. 1986; 46(12 Pt 1):6387-6392.

149. Greish K. Enhanced permeability and retention (EPR) effect for anticancer nanomedicine drug targeting. Methods Mol Biol. 2010;624:25-37.

150. Zysler RD, Lima E Jr, Vasquez Mansilla M, et al. A new quantitative method to determine the uptake of SPIONs in animal tissue and its application to determine the quantity of nanoparticles in the liver and lung of Balb-c mice exposed to the SPIONs. J Biomed Nanotechnol. 2013;9(1):142-145.

151. Prados J, Melguizo C, Perazzoli G, et al. Application of nanotechnology in the treatment and diagnosis of gastrointestinal cancers: review of recent patents. Recent Pat Anticancer Drug Discov. 2014;9(1):21-34.

152. De Jong WH, Borm PJ. Drug delivery and nanoparticles: applications and hazards. Int J Nanomedicine. 2008;3(2):133-149.

153. Leucuta SE. Nanotechnology for delivery of drugs and biomedical applications. Curr Clin Pharmacol. 2010;5(4):257-280.

154. Alexis F, Pridgen EM, Langer R, Farokhzad OC. Nanoparticle technologies for cancer therapy. Handb Exp Pharmacol. 2010;(197):55-86.

155. Farokhzad OC, Cheng J, Teply BA, et al. Targeted nanoparticleaptamer bioconjugates for cancer chemotherapy in vivo. Proc Natl Acad Sci U S A. 2006;103(16):6315-6320.

156. Lee PC, Chiou YC, Wong JM, Peng CL, Shieh MJ. Targeting colorectal cancer cells with single-walled carbon nanotubes conjugated to anticancer agent SN-38 and EGFR antibody. Biomaterials. 2013;34(34):8756-8765.

157. Shi J, Ma R, Wang L, et al. The application of hyaluronic acid-derivatized carbon nanotubes in hematoporphyrin monomethyl ether-based photodynamic therapy for in vivo and in vitro cancer treatment. Int $J$ Nanomedicine. 2013;8:2361-2373.

158. Li X, Gao J, Yang Y, et al. Nanomaterials in the application of tumor vaccines: advantages and disadvantages. Onco Targets Ther. 2013;6:629-634.

159. Liu Z, Fan AC, Rakhra K, et al. Supramolecular stacking of doxorubicin on carbon nanotubes for in vivo cancer therapy. Angew Chem Int Ed Engl. 2009;48(41):7668-7672. 
160. Coelho SC, Rocha S, Juzenas P, et al. Gold nanoparticle deliveryenhanced proteasome inhibitor effect in adenocarcinoma cells. Expert Opin Drug Deliv. 2013;10(10):1345-1352.

161. Li K, Wen S, Larson AC, et al. Multifunctional dendrimer-based nanoparticles for in vivo MR/CT dual-modal molecular imaging of breast cancer. Int J Nanomedicine. 2013;8:2589-2600.

162. FarrokhTakin E, Ciofani G, Puleo GL, et al. Barium titanate core-gold shell nanoparticles for hyperthermia treatments. Int J Nanomedicine. 2013;8:2319-2331.

163. Wang HJ, Yang L, Yang HY, et al. Antineoplastic activities of proteinconjugated silver sulfide nano-crystals with different shapes. J Inorg Biochem. 2010;104(1):87-91.

164. Pietilä M, Lehenkari P, Kuvaja P, et al. Mortalin antibody-conjugated quantum dot transfer from human mesenchymal stromal cells to breast cancer cells requires cell-cell interaction. Exp Cell Res. 2013;319(18): 2770-2780.

165. Zhang C, Ji X, Zhang Y, et al. One-pot synthesized aptamerfunctionalized CdTe: $\mathrm{Zn}^{2+}$ quantum dots for tumor-targeted fluorescence imaging in vitro and in vivo. Anal Chem. 2013;85(12): 5843-5849.

166. Daldrup-Link HE, Rummeny EJ, Ihssen B, Kienast J, Link TM. Ironoxide-enhanced MR imaging of bone marrow in patients with nonHodgkin's lymphoma: differentiation between tumor infiltration and hypercellular bone marrow. Eur Radiol. 2002;12(6):1557-1566.

167. Delsol G. [The 2008 WHO lymphoma classification]. Ann Pathol. 2008;28 Spec No 1(1):S20-S24. French.

168. Falini B, Pileri S, Zinzani PL, et al. ALK+lymphoma: clinic-pathological findings and outcome. Blood. 1999;93(8):2697-2706.

169. Stein H, Foss HD, Dürkop H, et al. CD30(+) anaplastic large cell lymphoma: a review of its histopathologic, genetic, and clinical features. Blood. 2000;96(12):3681-3695.

170. Ritter U, Damm-Welk C, Fuchs U, Bohle RM, Borkhardt A, Woessmann W. Design and evaluation of chemically synthesized siRNA targeting the NPM-ALK fusion site in anaplastic large cell lymphoma (ALCL). Oligonucleotides. 2003;13(5):365-373.

171. Piva R, Chiarle R, Manazza AD, et al. Ablation of oncogenic ALK is a viable therapeutic approach for anaplastic large-cell lymphomas. Blood. 2006;107(2):689-697.

172. Mori T, Oguro A, Ohtsu T, Nakamura Y. RNA aptamers selected against the receptor activator of NF-kappaB acquire general affinity to proteins of the tumor necrosis factor receptor family. Nucleic Acids Res. 2004;32(20):6120-6128.

173. Zhao N, Bagaria HG, Wong MS, Zu Y. A nanocomplex that is both tumor cell-selective and cancer gene-specific for anaplastic large cell lymphoma. J Nanobiotechnology. 2011;9:2.

174. Semete B, Booysen L, Lemmer Y, et al. In vivo evaluation of the biodistribution and safety of PLGA nanoparticles as drug delivery systems. Nanomedicine. 2010;6(5):662-671.

175. Witzig TE. Current treatment approaches for mantle-cell lymphoma. J Clin Oncol. 2005;23(26):6409-6414.

176. Williams ME, Connors JM, Dreyling MH, et al. Mantle cell lymphoma: report of the 2010 Mantle Cell Lymphoma Consortium Workshop. Leuk Lymphoma. 2011;52(1):24-33.

177. Delmonte A, Ghielmini M, Sessa C. Beyond monoclonal antibodies: new therapeutic agents in non-Hodgkin's lymphomas. Oncologist. 2009; 14(5):511-525

178. Hess G. New combinations for mantle cell lymphoma: concerted action needed. Lancet Oncol. 2011;12(4):315-316.

179. Uckun FM, Qazi S. Spleen tyrosine kinase as a molecular target for treatment of leukemias and lymphomas. Expert Rev Anticancer Ther. 2010;10(9):1407-1418.

180. Uckun FM, Ek RO, Jan ST, Chen CL, Qazi S. Targeting SYK kinasedependent anti-apoptotic resistance pathway in B-lineage acute lymphoblastic leukaemia (ALL) cells with a potent SYK inhibitory pentapeptide mimic. Br J Haematol. 2010;149(4):508-517.

181. Uckun FM, Goodman P, Ma H, Dibirdik I, Qazi S. CD22 EXON 12 deletion as a pathogenic mechanism of human B-precursor leukemia. Proc Natl Acad Sci U S A. 2010;107(39):16852-16857.
182. Cely I, Yiv S, Yin Q, et al. Targeting mantle cell lymphoma with anti-SYK nanoparticles. J Anal Oncol. 2012;1(1):1-9.

183. Muggia FM, Hainsworth JD, Jeffers S, et al. Phase II study of liposomal doxorubicin in refractory ovarian cancer: antitumor activity and toxicity modification by liposomal encapsulation. J Clin Oncol. 1997;15(3):987-993.

184. Muggia FM. Clinical efficacy and prospects for use of pegylated liposomal doxorubicin in the treatment of ovarian and breast cancers. Drugs. 1997;54 Suppl 4:22-29.

185. Shen C, Brozena AH, Wang Y. Double-walled carbon nanotubes: challenges and opportunities. Nanoscale. 2011;3(2):503-518.

186. Huang N, Wang H, Zhao J, Lui H, Korbelik M, Zeng H. Single-wall carbon nanotubes assisted photothermal cancer therapy: animal study with a murine model of squamous cell carcinoma. Lasers Surg Med. 2010;42(9):638-648.

187. Thakare VS, Das M, Jain AK, Patil S, Jain S. Carbon nanotubes in cancer theragnosis. Nanomedicine (Lond). 2010;5(8):1277-1301.

188. Ji SR, Liu C, Zhang B, et al. Carbon nanotubes in cancer diagnosis and therapy. Biochim Biophys Acta. 2010;1806(1):29-35.

189. Liu Z, Tabakman S, Welsher K, Dai H. Carbon nanotubes in biology and medicine: in vitro and in vivo detection, imaging and drug delivery. Nano Res. 2009;2(2):85-120.

190. Liu Z, Chen K, Davis C, et al. Drug delivery with carbon nanotubes for in vivo cancer treatment. Cancer Res. 2008;68(16):6652-6660.

191. Chaudhuri P, Soni S, Sengupta S. Single-walled carbon nanotubeconjugated chemotherapy exhibits increased therapeutic index in melanoma. Nanotechnology. 2010;21(2):025102.

192. Satsangi A, Roy SS, Satsangi RK, Vadlamudi RK, Ong JL. Design of a Paclitaxel prodrug conjugate for active targeting of an enzyme upregulated in breast cancer cells. Mol Pharm. 2014;11(6):1906-1918.

193. Singh S, Nalwa HS. Nanotechnology and health safety - toxicity and risk assessments of nanostructured materials on human health. J Nanosci Nanotechnol. 2007;7(9):3048-3070.

194. Radomski A, Jurasz P, Alonso-Escolano D, et al. Nanoparticleinduced platelet aggregation and vascular thrombosis. Br J Pharmacol. 2005;146(6):882-893.

195. Sayes CM, Liang F, Hudson JL, et al. Functionalization density dependence of single-walled carbon nanotubes cytotoxicity in vitro. Toxicol Lett. 2006;161(2):135-142.

196. Shvedova AA, Castranova V, Kisin ER, et al. Exposure to carbon nanotube material: assessment of nanotube cytotoxicity using human keratinocyte cells. J Toxicol Environ Health A. 2003;66(20): 1909-1926.

197. Warheit DB, Laurence BR, Reed KL, Roach DH, Reynolds GA, Webb TR. Comparative pulmonary toxicity assessment of single-wall carbon nanotubes in rats. Toxicol Sci. 2004;77(1):117-125.

198. Ravichandran P, Periyakaruppan A, Sadanandan B, et al. Induction of apoptosis in rat lung epithelial cells by multiwalled carbon nanotubes. J Biochem Mol Toxicol. 2009;23(5):333-344.

199. Reddy AR, Reddy YN, Krishna DR, Himabindu V. Pulmonary toxicity assessment of multiwalled carbon nanotubes in rats following intratracheal instillation. Environ Toxicol. 2012;27(4):211-219.

200. Muller J, Huaux F, Moreau N, et al. Respiratory toxicity of multiwall carbon nanotubes. Toxicol Appl Pharmacol. 2005;207(3): 221-231.

201. Loo C, Lin A, Hirsch L, et al. Nanoshell-enabled photonics-based imaging and therapy of cancer. Technol Cancer Res Treat. 2004;3(1): 33-40.

202. Niidome T, Yamagata M, Okamoto Y, et al. PEG-modified gold nanorods with a stealth character for in vivo applications. J Control Release. 2006; 114(3):343-347.

203. Kawano T, Yamagata M, Takahashi H, et al. Stabilizing of plasmid DNA in vivo by PEG-modified cationic gold nanoparticles and the gene expression assisted with electrical pulses. J Control Release. 2006; 111(3):382-389.

204. Hainfeld JF, Slatkin DN, Smilowitz HM. The use of gold nanoparticles to enhance radiotherapy in mice. Phys Med Biol. 2004;49(18): N309-N315. 
205. Simon T, Boca-Farcau S, Gabudean AM, Baldeck P, Astilean S. LED-activated methylene blue-loaded Pluronic-nanogold hybrids for in vitro photodynamic therapy. J Biophotonics. 2013;6(11-12): 950-959.

206. Boca S, Rugina D, Pintea A, Barbu-Tudoran L, Astilean S. Flowershaped gold nanoparticles: synthesis, characterization and their application as SERS-active tags inside living cells. Nanotechnology. 2011;22(5):055702.

207. O'Neal DP, Hirsch LR, Halas NJ, Payne JD, West JL. Photo-thermal tumor ablation in mice using near infrared-absorbing nanoparticles. Cancer Lett. 2004;209(2):171-176.

208. Waldman SA, Fortina P, Surrey S, Hyslop T, Kricka LJ, Graves DJ Opportunities for near-infrared thermal ablation of colorectal metastases by guanylyl cyclase C-targeted gold nanoshells. Future Oncol 2006;2(6):705-716.

209. Shahverdi AR, Fakhimi A, Shahverdi HR, Minaian S. Synthesis and effect of silver nanoparticles on the antibacterial activity of different antibiotics against Staphylococcus aureus and Escherichia coli. Nanomedicine. 2007;3(2):168-171.

210. Sondi I, Salopek-Sondi B. Silver nanoparticles as antimicrobial agent: a case study on E. coli as a model for Gram-negative bacteria. J Colloid Interface Sci. 2004;275(1):177-182.

211. Coulter JA, Hyland WB, Nicol J, Currell FJ. Radiosensitising nanoparticles as novel cancer therapeutics - pipe dream or realistic prospect? Clin Oncol (R Coll Radiol). 2013;25(10):593-603.

212. Satapathy SR, Mohapatra P, Preet R, et al. Silver-based nanoparticles induce apoptosis in human colon cancer cells mediated through p53. Nanomedicine (Lond). 2013;8(8):1307-1322.

213. Kemp MM, Kumar A, Mousa S, et al. Gold and silver nanoparticles conjugated with heparin derivative possess anti-angiogenesis properties. Nanotechnology. 2009;20(45):455104.

214. Sriram MI, Kanth SB, Kalishwaralal K, Gurunathan S. Antitumor activity of silver nanoparticles in Dalton's lymphoma ascites tumor model. Int J Nanomedicine. 2010;5:753-762.

215. Grosse S, Evje L, Syversen T. Silver nanoparticle-induced cytotoxicity in rat brain endothelial cell culture. Toxicol In Vitro. 2013;27(1): 305-313.

216. Sharma HS, Sharma A. Neurotoxicity of engineered nanoparticles from metals. CNS Neurol Disord Drug Targets. 2012;11(1) 65-80.
217. Powers CM, Levin ED, Seidler FJ, Slotkin TA. Silver exposure in developing zebrafish produces persistent synaptic and behavioral changes. Neurotoxicol Teratol. 2011;33(2):329-332.

218. Hussain SM, Hess KL, Gearhart JM, Geiss KT, Schlager JJ. In vitro toxicity of nanoparticles in BRL 3A rat liver cells. Toxicol In Vitro. 2005;19(7):975-983.

219. Smith AM, Dave S, Nie S, True L, Gao X. Multicolor quantum dots for molecular diagnostics of cancer. Expert Rev Mol Diagn. 2006;6(2): 231-244

220. Tang M, Xing T, Zeng J, et al. Unmodified CdSe quantum dots induce elevation of cytoplasmic calcium levels and impairment of functional properties of sodium channels in rat primary cultured hippocampal neurons. Environ Health Perspect. 2008;116(7):915-922.

221. Hardman R. A toxicologic review of quantum dots: toxicity depends on physiochemical and environmental factors. Environ Health Perspect. 2006;114(2):165-172.

222. Chan WC, Maxwell DJ, Gao X, Bailey RE, Han M, Nie S. Luminescent quantum dots for multiplexed biological detection and imaging. $\mathrm{Curr}$ Opin Biotechnol. 2002;13(1):40-46.

223. Dubertret B, Skourides P, Norris DJ, Noireaux V, Brivanlou AH, Libchaber A. In vivo imaging of quantum dots encapsulated in phospholipid micelles. Science. 2002;298(5599):1759-1762.

224. Gao X, Cui Y, Levenson RM, Chung LW, Nie S. In vivo cancer targeting and imaging with semiconductor quantum dots. Nat Biotechnol. 2004;22(8):969-976.

225. Lidke DS, Nagy P, Heintzmann R, et al. Quantum dot ligands provide new insights into erbB/HER receptor-mediated signal transduction. Nat Biotechnol. 2004;22(2):198-203.

226. Wu X, Liu H, Liu J, et al. Immunofluorescent labeling of cancer marker Her2 and other cellular targets with semiconductor quantum dots. Nat Biotechnol. 2003;21(1):41-46.

227. Hoshino A, Fujioka K, Oku T, et al. Quantum dots targeted to the assigned organelle in living cells. Microbiol Immunol. 2004;48(12):985-994.

228. Shiohara A, Hoshino A, Hanaki K, Suzuki K, Yamamoto K. On the cyto-toxicity caused by quantum dots. Microbiol Immunol. 2004;48(9): 669-675.

229. Hoshino A, Hanaki K, Suzuki K, Yamamoto K. Applications of T-lymphoma labeled with fluorescent quantum dots to cell tracing markers in mouse body. Biochem Biophys Res Commun. 2004; 314(1):46-53.
International Journal of Nanomedicine

\section{Publish your work in this journal}

The International Journal of Nanomedicine is an international, peerreviewed journal focusing on the application of nanotechnology in diagnostics, therapeutics, and drug delivery systems throughout the biomedical field. This journal is indexed on PubMed Central,

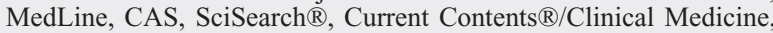

\section{Dovepress}

Journal Citation Reports/Science Edition, EMBase, Scopus and the Elsevier Bibliographic databases. The manuscript management system is completely online and includes a very quick and fair peer-review system, which is all easy to use. Visit http://www.dovepress.com/ testimonials.php to read real quotes from published authors. 